\title{
Nitrogen and potassium fertilization in yield and macronutrients contents of heliconia cv. Golden Torch
}

\author{
Márkilla Z. Beckmann-Cavalcante ${ }^{1}$, Genilda C. Amaral², Alcimar de S. e Silva², \\ Leonardo P. da S. Brito ${ }^{2}$, Augusto M. N. Lima ${ }^{1}$ \& Ítalo H. L. Cavalcante ${ }^{1}$ \\ ${ }^{1}$ Universidade Federal do Vale do São Francisco/Campus de Ciências Agrárias/Colegiado do Curso de Engenharia Agronômica. Petrolina, PE. E-mail: \\ markilla.beckmann@univasf.edu.br (Corresponding author); augusto.lima@univasf.edu.br; italohlc@ufpi.edu.br \\ ${ }^{2}$ Universidade Federal do Piauí/Campus Profa. Cinobelina Elvas/Colegiado de Engenharia Agronômica. Bom Jesus, PI. E-mail: genildacanuto@gmail.com; \\ alcimarsousa10@hotmail.com; leonardobrito@ufpi.edu.br
}

\section{Key words:}

Heliconia psittacorum

floriculture

fertilization

nutritional status

\begin{abstract}
A B S T R A C T
This study aimed to evaluate the effect of nitrogen $(\mathrm{N})$ and potassium $(\mathrm{K})$ fertilization in yield and contents of macronutrients in heliconia plants (Heliconia psittacorum x Heliconia spathocircinata Aristeguieta) cv. Golden Torch. The experiment was set in a randomized block design, in a $4 \times 4$ factorial, corresponding to $\mathrm{N}$ doses $\left(0,120,180\right.$ and $240 \mathrm{~g}$ of $\left.\mathrm{N} \mathrm{hole}^{-1}\right)$ and $\mathrm{K}$ doses $\left(0,120,180\right.$ and $240 \mathrm{~g}$ of $\mathrm{K}_{2} \mathrm{O}$ hole $\left.{ }^{-1}\right)$ with four replicates and five rhizomes per plot, under field conditions. After one year of cultivation, yield (number of flower stems per square meter) and the leaf contents of $\mathrm{N}, \mathrm{P}, \mathrm{K}, \mathrm{Ca}, \mathrm{Mg}$ and $\mathrm{S}$ were determined. The applied $\mathrm{N}$ doses did not influence either yield or the leaf contents of the evaluated macronutrients. $\mathrm{K}$ fertilization favored the increase in leaf $\mathrm{K}$ content and the decrease in the contents of $\mathrm{P}, \mathrm{Ca}$ and $\mathrm{Mg}$ in leaves of heliconias. Under the conditions of this experiment, it is recommended

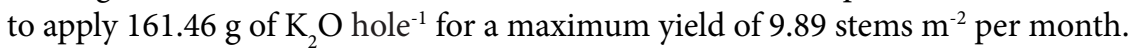

\section{Palavras-chave:}

Heliconia psittacorum

floricultura

fertilização

estado nutricional

\section{Adubação nitrogenada e potássica na produtividade e teores de macronutrientes em helicônia cv. Golden Torch}

\begin{abstract}
R E S U M O
Realizou-se este estudo com o objetivo de avaliar o efeito da adubação nitrogenada e potássica na produtividade e teores de macronutrientes em plantas de helicônia (Heliconia psittacorum x Heliconia spathocircinata Aristeguieta) cv. Golden Torch. O experimento foi conduzido segundo um delineamento experimental em blocos casualizados em esquema fatorial $4 \times 4$ correspondentes às doses de nitrogênio $\left(0,120,180\right.$ e 240 g cova $^{-1}$ de $\left.\mathrm{N}\right)$ e de potássio $\left(0,120,180\right.$ e $\left.240 \mathrm{~g}_{\text {cova }}{ }^{-1} \mathrm{de}_{2} \mathrm{O}\right)$ com quatro repetições e cinco rizomas por parcela, em condições de campo. Após um ano de cultivo determinaram-se a produtividade em termos de número de hastes florais por metro quadrado e os teores foliares de $\mathrm{N}, \mathrm{P}, \mathrm{K}$, $\mathrm{Ca}, \mathrm{Mg}$ e S. As doses de nitrogênio aplicadas não exerceram influência na produtividade nem nos teores foliares dos macronutrientes avaliados. A fertilização potássica favoreceu o aumento do teor de $\mathrm{K}$ foliar e o decréscimo dos teores de $\mathrm{P}$, Ca e Mg foliares; recomendamse, nas condições em que o experimento foi desenvolvido, 161,46 $\mathrm{g}$ cova $^{-1}$ de $\mathrm{K}_{2} \mathrm{O}$ para a produtividade máxima de 9,89 hastes $\mathrm{m}^{-2}$ ao mês.
\end{abstract}




\section{INTRODUCTION}

Plants from the genus Heliconia, belonging to the Heliconiaceae family, are used as garden plants or cut flowers, adapting to pots or composing flower arrangements, because they have important characteristics for marketing, such as the ornamental character, resistance to transport and post-harvest durability (Castro et al., 2007). The cultivation and marketing of heliconia flowers have greatly increased and, in parallel, the demand for products with essential quality also increases, in order to meet a progressively competitive market.

Among the post-harvest factors indispensable for obtaining quality production, the mineral nutrition of heliconias presents itself as one of the most significant, because, according to Beckmann-Cavalcante et al. (2015), the nutritional status influences vegetative growth and production of flowers, since the nutritional balance is one of the most relevant factors for post-harvest attributes, resistance to transport and storage of flowers, regulating physiological and biochemical processes of plant tissues, as reported by Burchi \& Prisa (2013).

According to Lamas (2002), heliconias have great demand for nutrients, especially nitrogen and potassium, requiring in increasing order the following macronutrients: $\mathrm{K}>\mathrm{N}>\mathrm{Ca}$ $>\mathrm{S}>\mathrm{Mg}>\mathrm{P}$; and micronutrients: $\mathrm{Mn}>\mathrm{Fe}>\mathrm{Zn}>\mathrm{B}>\mathrm{Cu}$. Despite the researches in the literature on the demands in the areas of soil fertility and mineral nutrition for heliconias (Albuquerque et al.; 2010; Farias et al., 2013; Paulino et al., 2013; Albuquerque et al., 2014; Viégas et al., 2014; Amaral et al., 2015; Beckmann-Cavalcante et al., 2015; Castro et al., 2015) and although these aspects constitute the most determinant factors for the production of this crop, as well as its quality and resistance to diseases, the results come from specific edaphoclimatic conditions. Thus, further studies are necessary for regions with potential for commercial cultivation, such as the state of Piauí.

Compared with other flowering species, the cultivation of heliconia usually demands great amounts of nutrients, especially N (Castro et al., 2011). Results obtained by Viégas et al. (2014) for Heliconia psittacorum x H. spathocircinata $\mathrm{cv}$. Golden Torch show that $\mathrm{N}$ was one of the most limiting nutrients for plant growth. Castro et al. (2015), in studies with deficiency of macronutrients, showed that visual symptoms appeared in the order of $\mathrm{N}, \mathrm{Mg}, \mathrm{K}, \mathrm{P}$ and $\mathrm{S}$, and also observed that the deficiency of $\mathrm{N}$ and $\mathrm{P}$ intensively affects the number of sprouts, leaf dry matter production, total number of leaves and leaf area, which are characteristics that can compromise the quality of flower stems to be produced. Amaral et al. (2015) also reported the importance of $\mathrm{N}$ and $\mathrm{K}$ fertilization in maintaining the quality of inflorescences of heliconia $\mathrm{cv}$. Golden Torch, showing that the dose of $180 \mathrm{~g} \mathrm{hole}^{-1}$, for both $\mathrm{N}$ and K, promoted higher durability of flower stems.

This study aimed to evaluate the effect of $\mathrm{N}$ and $\mathrm{K}$ fertilization on the yield and macronutrient contents of heliconias cv. Golden Torch.

\section{Material ANd Methods}

The study was carried out from July 29, 2011 to July 30, 2012, at the Floriculture Experimental Field of the Campus Profa. Cinobelina Elvas (CPCE) at the Federal University of Piauí (UFPI), located in the city of Bom Jesus-PI, Brazil (09 04' 53.0" S; 44 19' 41.6" W; $301 \mathrm{~m}$ ).

The climate of the region is BSh (hot semiarid), according to Köppen's classification. The climatic data along the experiment for air temperature, relative air humidity, wind speed, solar radiation and rainfall were daily monitored and the monthly means are shown in Figure 1.

The soil in the experimental area was classified as dystrophic Yellow Latosol, according to EMBRAPA (2006). Before installing the experiment, soil samples were collected in the layer of 0-20 $\mathrm{cm}$ for chemical and physical characterizations (Table 1).

Heliconia seedlings, from the hybrid Heliconia psittacorum $x$ Heliconia spathocircinata cv. Golden Torch, were produced using rhizomes collected in the active germplasm bank of the horticulture sector of the CPCE/UFPI. Prior to planting, rhizomes were standardized, leaving one bud in each. Then, the
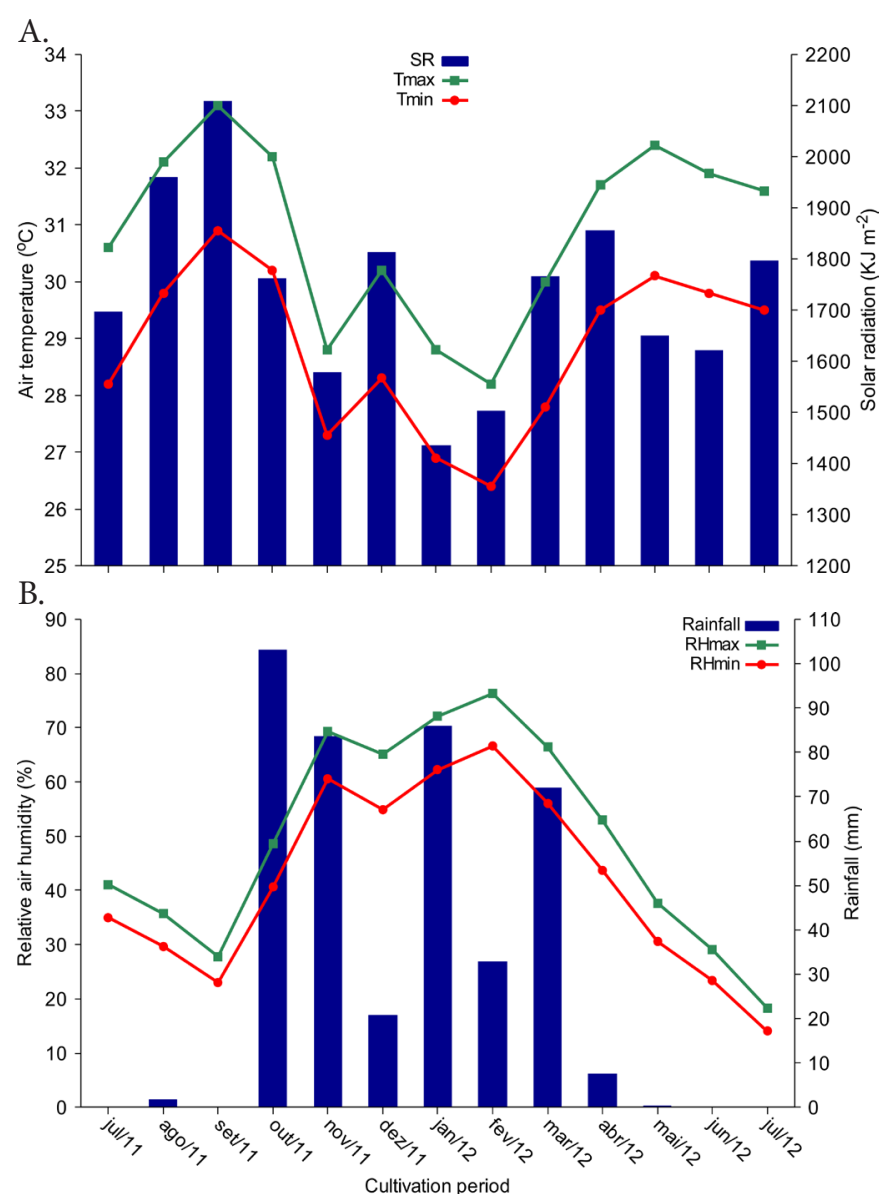

SR: Solar radiation; Tmax: Maximum temperature; Tmin: Minimum temperature; RHmax: Maximum relative humidity; RHmin: Minimum relative humidity

Figure 1. Monthly data of air temperature and solar radiation $(\mathrm{A})$ and relative air humidity and rainfall (B), along the cultivation of heliconia cv. Golden Torch

Table 1. Chemical and physical characteristics of the soil in the layer of $0-20 \mathrm{~cm}$ before experiment installation

\begin{tabular}{|c|c|c|c|c|c|c|c|c|c|c|c|c|c|c|}
\hline & $P$ & $\mathrm{~K}^{+}$ & $\mathrm{Ca}^{2+}$ & $\mathrm{Mg}^{2+}$ & $\mathrm{Ca}+\mathrm{Mg}$ & $\mathbf{A l}^{3+}$ & $\mathrm{H}+\mathrm{Al}$ & CEC & \multirow{3}{*}{$\begin{array}{c}\mathbf{O M} \\
\operatorname{dag}^{\mathbf{k g}^{-1}} \\
1.6\end{array}$} & $\mathrm{~m}$ & V & \multirow{3}{*}{$\frac{1}{\%}$} & Silt & \multirow[t]{2}{*}{ Sand } \\
\hline $\mathrm{pH}$ & & & & & $\mathrm{cmo}$ & & & & & & & & & \\
\hline 4.2 & 6 & 104 & 0.5 & 0.2 & 0.7 & 0.5 & 2.6 & 3.6 & & 42 & 27 & & 11 & 58 \\
\hline
\end{tabular}

pH - Potential of hydrogen in water; CEC - Cation exchange capacity; OM - Organic matter; $\mathrm{m}$ - Aluminum saturation; $\mathrm{V}$ - Base saturation 
Table 2. Analysis of variance ( $\mathrm{F}$ value) for the yield of flower stems (NFS $\mathrm{m}^{-2}$ ) and contents of nitrogen (N), phosphorus $(\mathrm{P})$, potassium $(\mathrm{K})$, calcium $(\mathrm{Ca})$, magnesium $(\mathrm{Mg})$ and sulfur $(\mathrm{S})$ in leaves of heliconia cv. Golden Torch, as a function of $\mathrm{N}$ and $\mathrm{K}$ doses

\begin{tabular}{|c|c|c|c|c|c|c|c|}
\hline Source of variation & $\begin{array}{c}\text { Yield } \\
\text { NFS } \text { m-2 }^{-2}\end{array}$ & N & $\mathbf{P}$ & K & $\mathrm{Ca}$ & $\mathrm{Mg}$ & $S$ \\
\hline $\mathrm{N}$ doses ( $\mathrm{F}$ value) & $1.38^{\mathrm{ns}}$ & $2.44^{\mathrm{ns}}$ & $2.85^{\text {ns }}$ & $1.13^{\text {ns }}$ & $0.91^{\text {ns }}$ & $1.19^{\text {ns }}$ & $0.39^{\text {ns }}$ \\
\hline $\mathrm{K}$ doses ( $\mathrm{F}$ value) & $3.70^{\star}$ & $2.41^{\text {ns }}$ & $2.71 *$ & $16.03^{* *}$ & $2.86^{*}$ & $22.61 * \star$ & $2.77^{\mathrm{ns}}$ \\
\hline Interaction N x K (F value) & $0.89^{\text {ns }}$ & $0.66^{\text {ns }}$ & $1.02^{\text {ns }}$ & $0.80^{\text {ns }}$ & $1.59 \mathrm{~ns}$ & $1.42^{\text {ns }}$ & $0.33^{\text {ns }}$ \\
\hline Blocks (F value) & $3.18^{*}$ & $0.75^{\text {ns }}$ & $1.85^{\text {ns }}$ & $2.98^{*}$ & $1.35^{\mathrm{ns}}$ & $1.87^{\mathrm{ns}}$ & $1.64^{\mathrm{ns}}$ \\
\hline CV (\%) & 25.70 & 6.97 & 13.76 & 17.18 & 15.89 & 20.56 & 10.89 \\
\hline
\end{tabular}

${ }^{*}$ and ${ }^{*}$ Significant at 0.05 and 0.1 probability levels, respectively; ns Not significant $(\mathrm{p} \geq 0.05)$; CV - Coefficient of variation; NFS - Number of flower stems

rhizomes were immersed in solution of sodium hypochlorite at $5 \%$ for $15 \mathrm{~min}$ for asepsis and placed in 2-L plastic bags filled with substrate composed of sand + cattle manure in the proportion of 2:1 (v/v), under partial shade and irrigated once a day, according to Beckmam-Cavalcante et al. (2011). After 60 days, the seedlings were transplanted to the definitive place in the field under full sun.

Soil $\mathrm{pH}$ was corrected 30 days before seedling transplantation, with the application of $1,080 \mathrm{~kg} \mathrm{ha}^{-1}$ of dolomitic limestone (RNV $=80 \%$ ), since heliconias demand slightly acidic soils and the adequate $\mathrm{pH}$ for cultivation is between 4.5 and 6.5 (Lamas, 2002). After 30 days for the reaction of limestone in the soil ( $\mathrm{pH}$ $=5.5$ ), one seedling was planted in each hole, each of which was opened with dimension of twice the diameter of the rhizome, i.e., approximately $20 \mathrm{~cm}$ wide and $20 \mathrm{~cm}$ deep, maintaining the pseudostem exposed. Planting was performed in single rows with spacing of $2.0 \times 3.0 \mathrm{~m}(2.0 \mathrm{~m}$ between plants and $3.0 \mathrm{~m}$ between rows), with density of 1,666 plants ha ${ }^{-1}$, according to the recommendation of Lamas (2002).

The experiment was set in a randomized block design and the treatments, arranged in a $4 \times 4$ factorial scheme, corresponded to four $\mathrm{N}$ doses $\left(0,120,180\right.$ and $240 \mathrm{~g} \mathrm{hole}^{-1}$ of $\mathrm{N})$ and four $\mathrm{K}$ doses $\left(0,120,180\right.$ and $240 \mathrm{~g} \mathrm{hole}^{-1}$ of $\left.\mathrm{K}_{2} \mathrm{O}\right)$, with four replicates and five rhizomes per plot, totaling 320 plants, in an area of 0.19 ha.

Basal phosphate fertilization was performed by applying $45 \mathrm{~g} \mathrm{hole}^{-1}$ of single superphosphate $\left(18 \% \mathrm{P}_{2} \mathrm{O}_{5}\right)$, mixed to the soil in the planting hole. $\mathrm{N}$ and $\mathrm{K}$ fertilizers used in the experiment were $\mathrm{KCl}\left(58 \%\right.$ of $\left.\mathrm{K}_{2} \mathrm{O}\right)$ and urea ( $45 \%$ of $\left.\mathrm{N}\right)$, respectively. $\mathrm{N}$ and $\mathrm{K}$ doses were divided into three equal applications, at 3, 6 and 9 months after the establishment of seedlings at the field, based on the recommendations of Oliveira et al. (2006).

During the application of $\mathrm{N}$ and $\mathrm{K}$, weed control was performed around the clumps and small furrows were dug about 15 to $20 \mathrm{~cm}$ from the clumps with depth sufficient to contain the amount of fertilizer applied. After that, the fertilizer was covered with the soil previously removed from the furrow.

Irrigation was performed using micro-sprinklers with one line of emitters interspersed with every two planting rows, with mean flow rate of $43 \mathrm{~L} \mathrm{~h}^{-1}$ and radius of throw of $6.2 \mathrm{~m}$. During the experiment, manual weedings were performed in order to maintain the experimental area without unwanted plants.

After one year of cultivation, yield was determined by the number of flower stems per square meter $\left(\mathrm{NFS} \mathrm{m}^{-2}\right)$, counting the marketable inflorescences. For the determination of the contents of macronutrients, healthy heliconia leaves were collected in full flowering from two clumps per plot, washed in distilled water and dried in a forced-air oven at $+65^{\circ} \mathrm{C}$ until constant mass. After drying, the plant material was weighed, passed in a Wiley-type mill and digested by the nitric-perchloric mixture (3:1) for the determination of macronutrients (N, P, $\mathrm{K}, \mathrm{Ca}, \mathrm{Mg}$ and S), following the methodology proposed by Malavolta et al. (1997). N was determined using the Kjeldahl method and titration with $\mathrm{NaOH} 1 \mathrm{~mol} \mathrm{~L}^{-1}$. P was quantified through photocolorimetry and the $\mathrm{K}$ content was determined by flame emission photometry. The contents of $\mathrm{Ca}$ and $\mathrm{Mg}$ were determined through atomic absorption spectrophotometry and $S$ through turbidimetry.

The data were subjected to analysis of variance by $\mathrm{F}$ test in order to verify significant effects of $\mathrm{N}$ and $\mathrm{P}$ fertilizer doses, using the program Assistat. Since no significant interactions occurred for the studied factors, simple regression analyses were performed for the effect of $\mathrm{K}$ doses using the statistical package SigmaPlot version 10.0 (SPSS, 2006), identifying the ones with the best fit, according to the coefficient of determination $\left(\mathrm{R}^{2}\right)$.

\section{Results AND Discussion}

According to the results of the analysis of variance (Table 2 ), only the doses of $\mathrm{K}_{2} \mathrm{O}$ affected flower stem yield and the contents of $\mathrm{P}, \mathrm{K}, \mathrm{Ca}$ and $\mathrm{Mg}$ in the leaves of heliconia $\mathrm{cv}$. Golden Torch.

Yield, given by the number of flower stems as a function of $\mathrm{K}_{2} \mathrm{O}$ doses, fitted to a quadratic model with maximum value of 9.89 stems m$^{-2}$ per month for a dose of $161.46 \mathrm{~g} \mathrm{hole}^{-1}$ (Figure 2). This result also shows that, despite the good content of available $\mathrm{K}$ in the soil (104 $\mathrm{mg} \mathrm{dm}^{-3}$, Table 1), according to the interpretation of Cantarutti et al. (2007), there was an increase

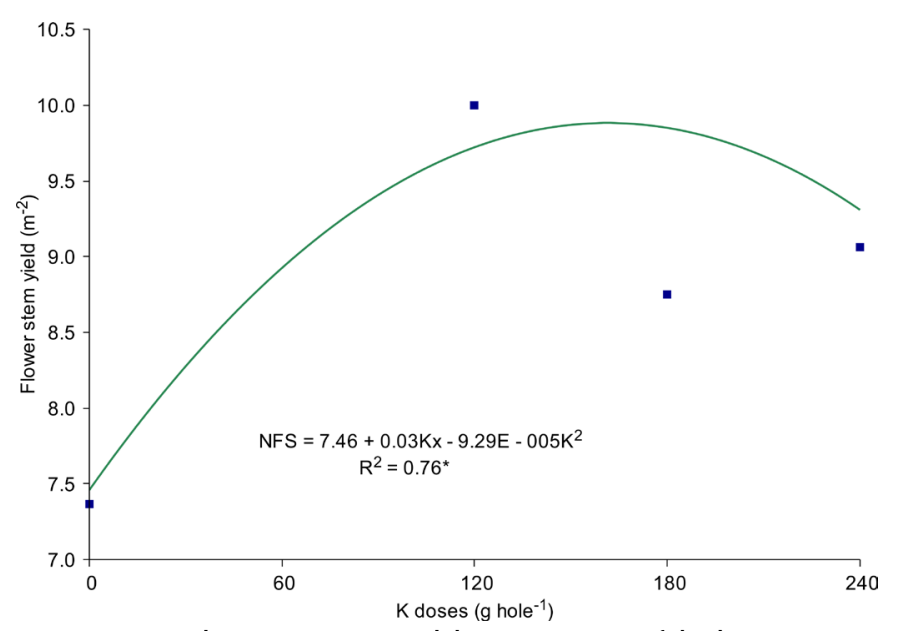

Figure 2. Flower stem yield (NFS $\left.\mathrm{m}^{-2}\right)$ of heliconia $\mathrm{cv}$. Golden Torch as a function of potassium doses 
in flower stem yield with the increment in $\mathrm{K}_{2} \mathrm{O}$ doses, which shows the high demand for this nutrient by heliconia plants.

Considering edaphoclimatic conditions different from that in the present study, similar results of yield were obtained by Albuquerque et al. (2010), who collected from 120.3 to 126.5 flower stems $\mathrm{m}^{-2}$, using organo-mineral fertilization in the cultivation of heliconia cv. Golden Torch, in twelve months of evaluation, which represented an amount of 10 to 10.5 stems per month. Similarly, Paulino et al. (2013) obtained mean yield of 9.3 to 10.2 stems $\mathrm{m}^{-2}$ per month when different sources and doses of silicon were applied in the soil cultivated with heliconia cv. Golden Torch.

In a study evaluating the effect of NPK doses on growth and yield variables of inflorescences of Heliconia sp., Ferreira \& Oliveira (2003) observed that the addition of $\mathrm{K}$ doses promoted increase in the number of inflorescences. The behavior observed in Figure 2 can be explained by the role that $\mathrm{K}$ plays in functions essential to plants, such as enzymatic activation, protein synthesis, absorption and transport of ions, photosynthesis and cell respiration (Römheld \& Kirby, 2010).

Evaluating post-harvest characteristics of the first flower stem of heliconias cv. Golden Torch, under macronutrient deficiency, Castro et al. (2007) observed that K deficiency resulted in lower values of dry matter of the flower stem, lower post-harvest durability and accumulation of carbohydrates in the leaves. Under conditions of K deficiency, plants accumulate more carbohydrates in the leaves, due to the restriction of sucrose transport, decrease in dry matter production and alteration in the pattern of partitioning of photoassimilates between source and sink plant tissues (Hermans et al., 2006). Flower stems with higher contents of soluble carbohydrates in the leaves cause a delay in inflorescence emergence (Castro et al., 2007).

The increment in $\mathrm{K}_{2} \mathrm{O}$ doses in the soil caused a reduction in the $\mathrm{P}$ contents of heliconia leaves (Figure $3 \mathrm{~A}$ ), which can be attributed to the negative relationship between $\mathrm{P}$ and $\mathrm{K}$ described in the literature by Marschner (2005). Morton et al. (2010), evaluating the nutritional balance between $\mathrm{K}$ and $\mathrm{P}$ in pasture, observed no significant interaction between the leaf contents of $\mathrm{P}$ and $\mathrm{K}$, attributing it to the fact that high $\mathrm{K}$ rates cause luxury consumption of $\mathrm{P}$, thus increasing the balance in the nutrition regarding these nutrients.

Leaf $\mathrm{P}$ contents ranged from 1.23 to $1.41 \mathrm{~g} \mathrm{~kg}^{-1}$ and, therefore, are below the values considered as optimal by Mills \& Jones Jr. (1996) for heliconias cv. Golden Torch (2.7 to $3.8 \mathrm{~g} \mathrm{~kg}^{-1}$ ), although deficiency symptoms were not observed in the plants in the field. According to Cantarutti et al. (2007), the appearance of symptoms of nutritional deficiency represents the late stage of a process in which growth and production may suffer irreversible losses. Thus, growth rate may be reduced and the deficiency symptoms related to the already caused metabolic disorders may appear only later. On the other hand, the mean contents of $\mathrm{P}$ in the leaves in the present study were higher than the mean of $1.17 \mathrm{~g} \mathrm{~kg}^{-1}$ observed by Santos et al. (2012), but lower than the range of 1.87 to $1.93 \mathrm{~g} \mathrm{~kg}^{-1}$ reported by Cerqueira et al. (2008) and $1.77 \mathrm{~g} \mathrm{~kg}^{-1}$ obtained by Viégas et al. (2014) for the cultivation of heliconias.

Evaluating the effect of the interaction of $\mathrm{N}$ and $\mathrm{K}$ on the nutrition of wheat plants in greenhouse, Viana \& Kiehl (2010)
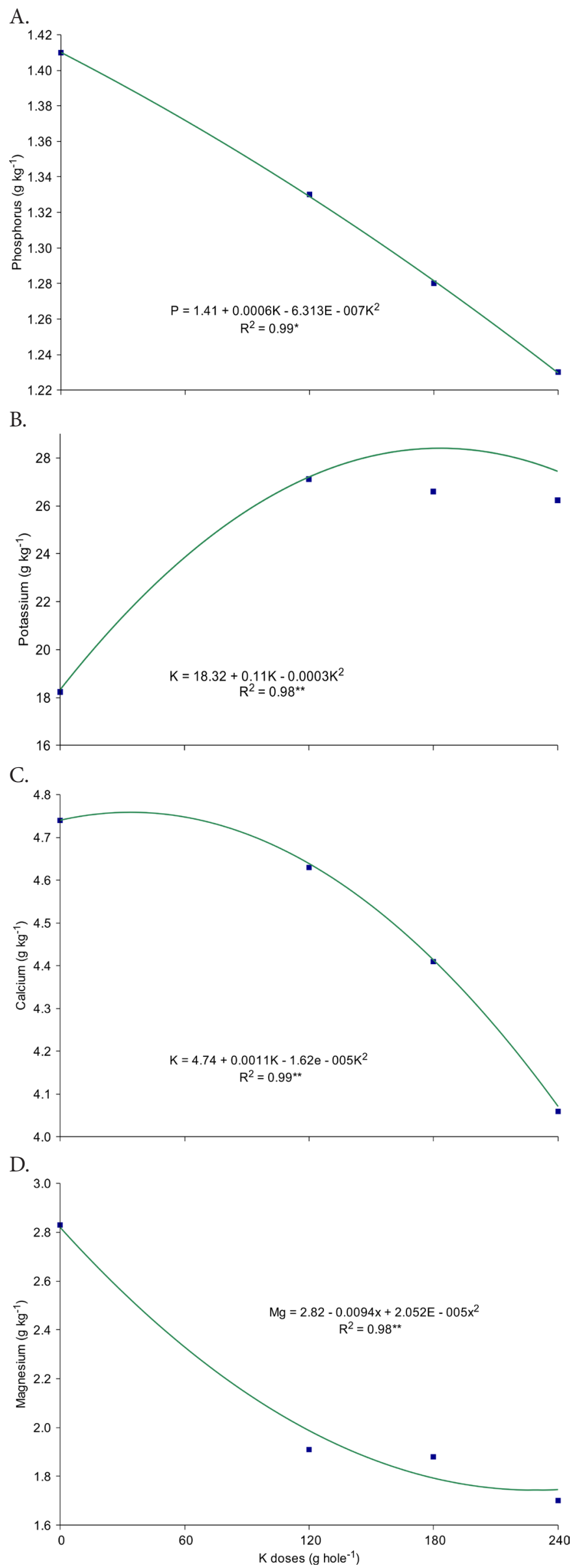

Figure 3. Contents of phosphorus (A), potassium (B), calcium (C) and magnesium (D) in leaves of heliconia CV. Golden Torch as a function of potassium doses 
observed that shoot $\mathrm{P}$ content was lower for the treatments with higher $\mathrm{K}$ doses. On the other hand, the highest shoot $\mathrm{P}$ content was obtained with the supply of a higher $\mathrm{N}$ dose combined with the lowest $\mathrm{K}$ dose. This association also promoted lower plant growth due to the absence of $\mathrm{K}$, which caused accumulation of $\mathrm{P}$ in plant tissue.

Leaf $\mathrm{K}$ contents in heliconia increased until the dose of 120 $\mathrm{g} \mathrm{hole}^{-1}$ of $\mathrm{K}_{2} \mathrm{O}$, followed by a progressive decrease until the highest dose, i.e., $240 \mathrm{~g}$ hole $^{-1}$ of $\mathrm{K}_{2} \mathrm{O}$ (Figure 3B). The mean leaf $\mathrm{K}$ contents observed in the present study are between 18.23 and $27.1 \mathrm{~g} \mathrm{~kg}^{-1}$, and are higher than the range of 17.4 to 18.7 $\mathrm{g} \mathrm{kg}^{-1}$ observed by Santos et al. (2012), the amplitude of 14.0 to $16.5 \mathrm{~g} \mathrm{~kg}^{-1}$ (Cerqueira et al., 2008) and the value of $2.59 \mathrm{~g}$ $\mathrm{kg}^{-1}$ (Viégas et al., 2014). The leaf $\mathrm{K}$ contents in this study are below the range of 35-45 $\mathrm{g} \mathrm{kg}^{-1}$ reported by Atehortua (1997), although no visual symptom of deficiency was observed at the field. According to Mills \& Jones Jr. (1996), the leaf K contents considered as optimal for heliconias cv. Golden Torch are in the interval from 12.7 to $21.3 \mathrm{~g} \mathrm{~kg}^{-1}$.

The increment in $\mathrm{K}_{2} \mathrm{O}$ doses in the soil resulted in reduction of $14 \%$ in leaf $\mathrm{Ca}$ contents and $40 \%$ in leaf $\mathrm{Mg}$ contents in heliconia plants (Figures $3 \mathrm{C}$ and D). Büll et al. (1998) evaluated the effects of the relationships $(\mathrm{Ca}+\mathrm{Mg}) / \mathrm{K}$ in the soil on the development, nutrient absorption and production of bulbs in the garlic crop cv. "Roxo Pérola de Caçador" in greenhouse. These authors observed that shoot $\mathrm{K}$ contents increased proportionally to the applied amounts of $\mathrm{K}$, and the inverse occurred for the contents of $\mathrm{Ca}$ and Mg. Similar results were obtained by Soares et al. (1983) and Rosolem et al. (1984), evidencing an antagonistic effect of $\mathrm{K}$ on the absorption of divalent cations. Büll et al. (1998) also observed that the absorption of $\mathrm{K}^{+}$increased with the values of its activity in solution, and the opposite occurred with the absorption of $\mathrm{Ca}^{2+}$ and $\mathrm{Mg}^{2+}$. In addition, despite the activities of $\mathrm{Ca}^{2+}$ and $\mathrm{Mg}^{2+}$ in solution with the increase in the applied $\mathrm{K}$ content, the absorption of these cations by plants decreased with correlation coefficients of $r=-0.88$ and $r=-0.95$, for $\mathrm{Ca}$ and $\mathrm{Mg}$ respectively, demonstrating that the absorption of these divalent cations was more controlled by the activity of $\mathrm{K}^{+}$in solution than by the activity of $\mathrm{Ca}^{2+}$ and $\mathrm{Mg}^{2+}$ in the soil solution, corroborating the observation of Rosolem et al. (1984), which also confirms that, in terms of absorption of nutrients by plants, the equilibrium of cations in solution can be more important than the concentration of the nutrient in the solution.

The reduction of $\mathrm{Ca}$ and $\mathrm{Mg}$ contents in the leaf tissues of heliconia can be attributed, according to Marschner (2005), to the competitive effect among the ions $\mathrm{K}^{+}, \mathrm{Ca}^{2+}$ and $\mathrm{Mg}^{2+}$ in the soil. The binding sites with the transporters situated in the plasmatic membrane of root cells for $\mathrm{Ca}^{2+}$ and $\mathrm{Mg}^{2+}$ are the same for $\mathrm{K}^{+}$, leading to competitive inhibition between these ions in the soil with the increase in the applied doses of $\mathrm{K}_{2} \mathrm{O}$, which results in the reduction of leaf contents of $\mathrm{Ca}$ and $\mathrm{Mg}$.

The absorption of nutrients by plants depends on the activity of the ions in the solution and exchange sites (Rosolem et al., 1984). The absorption of $\mathrm{K}^{+}, \mathrm{Ca}^{2+}$ and $\mathrm{Mg}^{2+}$ is competitive and the antagonism implies that the excess of one of these elements results in the decrease in the absorption of the other
(Marschner, 2005), which can lead to the reduction of growth and production of some crops, such as saccharine sorghum (Rosolem et al., 1984). The leaf contents of $\mathrm{Ca}$ and $\mathrm{Mg}$ ranged from 4.06 to 4.74 and from 1.7 to $2.83 \mathrm{~g} \mathrm{~kg}^{-1}$, respectively, which are below the optimal values defined for heliconias (Ca: 7.5 to $8.1 \mathrm{~g} \mathrm{~kg}^{-1}$; Mg: 3.3 to $3.8 \mathrm{~g} \mathrm{~kg}^{-1}$ ) (Mills \& Jones Jr., 1996). According to Atehortua (1997), the leaf contents of Ca and $\mathrm{Mg}$ considered as adequate for heliconias must be between 12.6 and $17.5 \mathrm{~g} \mathrm{~kg}^{-1}$ and 2.5 and $8.0 \mathrm{~g} \mathrm{~kg}^{-1}$, respectively. In another study, with deficiency of macronutrients in plants of heliconia cv. Golden Torch, Viégas et al. (2014) determined the leaf contents of macronutrients and obtained, for $\mathrm{Ca}$ and $\mathrm{Mg}$, respectively, 9.22 and $4.46 \mathrm{~g} \mathrm{~kg}^{-1}$, for the application of complete fertilization (macro + micronutrient), but without any symptoms of deficiency.

\section{Conclusions}

1. Only potassium fertilization affected flower stem yield and the leaf contents of P, K, Ca and Mg of heliconia cv. Golden Torch for the doses used in this study.

2. Potassium fertilization favors the increase in leaf $\mathrm{K}$ content and decrease in the leaf contents of $\mathrm{P}, \mathrm{Ca}$ and $\mathrm{Mg}$ in heliconia cv. Golden Torch.

3. Under the conditions of this study, the dose of 161.46 $\mathrm{g} \mathrm{hole}^{-1}$ of $\mathrm{K}_{2} \mathrm{O}$ is recommended for maximum yield of 9.89 flower stems $\mathrm{m}^{-2}$ per month.

\section{ACKNOWLedgments}

To the Piauí Research Support Foundation - FAPEPI, for the financial support granted to the project (Edict FAPEPI/ MCT/CNPq/CT-INFRA No 010/2009).

\section{Literature Cited}

Albuquerque, A. W. de.; Rocha, E. S.; Costa, J. P. V. da; Farias, A. P.; Bastos, A. L. Produção de helicônia Golden Torch influenciada pela adubação mineral de orgânica. Revista Brasileira de Engenharia Agrícola e Ambiental, v.14, p.1052- 1058, 2010. http:// dx.doi.org/10.1590/S1415-43662010001000005

Albuquerque, A. W. de; Santos, J. M. dos; Farias, A. P. de. Produtividade e qualidade pós-colheita de Helicônia Golden Torch submetida a fontes e doses de silício. Revista Brasileira de Engenharia Agrícola e Ambiental, v.18, p.173-179, 2014. http://dx.doi.org/10.1590/ S1415-43662014000200007

Amaral, G. C.; Beckmann-Cavalcante, M. Z.; Brito, L. P. da S.; Lima, M. P. D.; Osajima, J. A. Conservação de inflorescências de helicônias previamente adubadas com doses crescentes de nitrogênio e potássio. Revista Caatinga, v.28, p.61-67, 2015.

Atehortua, L. Heliconias: A new challange for the Colombian floricultural industry. Biotechnology and Development Monitor, n.31, p.2021-2021, 1997.

Beckmann-Cavalcante, M. Z.; Amaral, G. C.; Avelino, R. C.; Silva, A. A.; Silva, A. de S. e; Oliveira, J. B. da S. Produção de inflorescências de helicônia cv. Golden Torch sob adubação nitrogenada e potássica. Comunicata Scientiae, v.6, p.65-73, 2015. 
Beckmann-Cavalcante, M. Z.; Amaral, G. C.; Silva, A. A.; Cavalcante, Í. H. L.; Lima, M. P. D. Alternative substrates for production of Heliconia psittacorum L. seedlings under shade and open field conditions. African Journal of Biotechnology, v.10, p.15272-15277, 2011. http://dx.doi.org/10.5897/AJB11.1028

Büll, L. T.; Villas-Bôas; R. L.; Nakagawa, J. Variações no balanço catiônico do solo induzidas pela adubação potássica e efeitos na cultura do alho vernalizado. Scientia Agricola, v.55, p.456-464, 1998. http://dx.doi.org/10.1590/S0103-90161998000300014

Burchi, G.; Prisa, D. Preharvest conditions that can improve the postharvest quality of ornamentals. Acta Horticulturae, n.970, p.23-28, 2013. http://dx.doi.org/10.17660/ActaHortic.2013.970.1

Cantarutti, R. B.; Barros, N. F.; Martinez, H. E. P.; Novais, R. F. Avaliação da fertilidade do solo e recomendação de fertilizantes. In: Novais, R. F.; Alvarez V., V. H.; Fontes, R. L. F.; Cantarutti, R. B.; Neves, J. C. L. (ed.). Fertilidade do solo. 1.ed. Viçosa: Sociedade Brasileira de Ciência do Solo, 2007. p.769-850.

Castro, A. C. R. de; Aragão, F. A. S.; Loges, V.; Costa, A. S.; Willadino, L. G.; Castro, M. F. A. Macronutrients contents in two development phases of Heliconia psittacorum. Acta Horticulturae, n.886, p.285288, 2011. http://dx.doi.org/10.17660/ActaHortic.2011.886.40

Castro, A. C. R. de; Loges, V.; Costa, A. S.; Castro, M. F. A.; Aragão, F. A. S.; Willadino, L. G. Hastes florais de helicônia sob deficiência de macronutrientes. Pesquisa Agropecuária Brasileira, v.42, p.12991306, 2007. http://dx.doi.org/10.1590/S0100-204X2007000900012

Castro, A. C. R. de; Willadino, L. G.; Loges, V.; Castro, M. F. A. de; Aragão, F. A. S. de. Macronutrients deficiency in Heliconia psittacorum x Heliconia spathocircinata 'Golden Torch'. Revista Ciência Agronômica, v.46, p.258-265, 2015. http://dx.doi. org/10.5935/1806-6690.20150005

Cerqueira, L. L.; Fadigas, F. S.; Pereira, F. A.; Gloaguen, T. V.; Costa, J. A. Desenvolvimento de Heliconia psittacorum e Gladiolus hortulanus irrigados com águas residuárias tratadas. Revista Brasileira de Engenharia Agrícola e Ambiental, v.12, p.606-613, 2008. http://dx.doi.org/10.1590/S1415-43662008000600006

EMBRAPA - Empresa Brasileira de Pesquisa Agropecuária. Sistema brasileiro de classificação de solos. Recife: Embrapa Solos, 2006. 306p.

Farias, A. P.; Albuquerque, A. W. de; Moura Filho, G.; Reis, L. S. Produtividade da Heliconia psittacorum x Heliconia pathocircinada cv. Golden Torch sob diferentes fontes de adubação orgânica. Revista Brasileira de Engenharia Agrícola e Ambiental, v.17, p.713720, 2013. http://dx.doi.org/10.1590/S1415-43662013000700004

Ferreira, L. B.; Oliveira, S. A. Estudo de doses de NPK nas variáveis de crescimento e produtividade de inflorescências de Heliconia sp. Revista Brasileira de Horticultura Ornamental, v.9, p.121127,2003

Hermans, C.; Hammond, J. P.; White, P. J.; Verbruggen, N. How do plants respond to nutrient shortage by biomass allocation. Trends in Plant Science, v.11, p.610-617, 2006. http://dx.doi.org/10.1016/j. tplants.2006.10.007
Lamas, A. da M. Floricultura tropical: técnicas de cultivo e póscolheita de flores e folhagens. Fortaleza: Instituto Frutal, 2002, 135p.

Malavolta, E.; Vitti, G. C.; Oliveira, S. A. Avaliação do estado nutricional das plantas: princípios e aplicações. 2.ed. Piracicaba: Associação Brasileira para Pesquisa da Potassa e do Fosfato, 1997. 281p.

Marschner, H. Mineral nutrition of higher plants. 6.ed. London: Academic Press, 2005. 889p.

Mills, H. A.; Jones Jr., J. B. Plant analysis handbook II: A practical sampling, preparation, analysis and interpretation guide. Athens: MicroMacro, 1996. 456p.

Morton, J. D.; Smith, L. C.; Dodds, K. G.; Catto, W. D. Balanced and adequate potassium and phosphorus nutrition of pasture New Zealand Journal of Agricultural Research, v.44, p.269-277, 2010. http://dx.doi.org/10.1080/00288233.2001.9513484

Oliveira, R. F. de; Viégas, I. J. M.; Conceição, H. E. O.; Frazão, D. A. C.; Chagas, J. O. Produção de flores de Heliconia bihai com adubação mineral e orgânica. Belém: EMBRAPA, 2006. 5p. Comunicado Técnico, 166.

Paulino, A. da S.; Albuquerque, A. W.; Moura Filho, G., Pereira, F. R. da S. Helicônia "Golden Torch": Produtividade e qualidade póscolheita sob diferentes fontes e doses de silício. Revista Brasileira de Engenharia Agrícola e Ambiental, v.17, p.615-621, 2013. http:// dx.doi.org/10.1590/S1415-43662013000600007

Römheld, V.; Kirkby, E. A. Research on potassium in agriculture: needs and prospects. Plant Soil, v.335, p.155-180, 2010. http:// dx.doi.org/10.1007/s11104-010-0520-1

Rosolem, C. A.; Machado, J. K.; Brinholi, O. Efeito das relações Ca/ $\mathrm{Mg}, \mathrm{Ca} / \mathrm{Ke} \mathrm{Mg} / \mathrm{K}$ do solo na produção de sorgo sacarino. Pesquisa Agropecuária Brasileira, v.19, p.1443-1448, 1984.

Santos, O. S. N.; Paz, V. P. S.; Gloaguen, T. V.; Teixeira, M. B.; Fadigas, F. S.; Costa, J. A. Crescimento e estado nutricional de helicônia irrigada com água residuária tratada em casa de vegetação. Revista Brasileira de Engenharia Agrícola e Ambiental, v.16, p.820-827, 2012. http://dx.doi.org/10.1590/S1415-43662012000800002

Soares, E.; Lima, L. A.; Mischan, M. M.; Mello, F. A. F.; Boaretto, A. E. Efeito da relação entre teores trocáveis de Ca e Mg do solo na absorção de K por plantas de centeio. Revista de Agricultura, 58:315-330, 1983.

SPSS. Inc. SigmaPlot. Version 10.0. 2006. CD Rom

Viana, E. M.; Kiehl, J. C. Interação de nitrogênio e potássio na nutrição, no teor de clorofila e na atividade da redutase do nitrato em plantas de trigo. Bragantia, v.69, p.975-982, 2010. http://dx.doi. org/10.1590/S0006-87052010000400024

Viégas, I. J. M.; Rodrigues, É. F.; Silva, D. A. S.; Silva, S. P.; Conceição, H. E. O.; Oliveira Neto, C. F.; Monfort, L. E. F.; Silva, R. T. L.; Mariano, D. C.; Okumura, R. S. Growth and visual symptoms of macronutrient deficiency and zinc in Heliconia psittacorum cv. Golden Torch. Journal of Food, Agriculture \& Environment, v.12, p.169-173, 2014. 